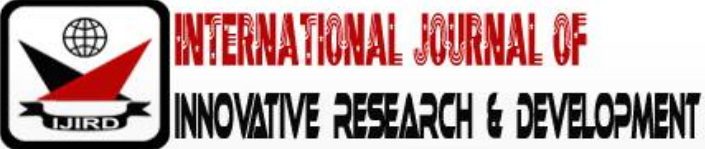

ISSN 2278 - 0211 (Online)

\section{Parents' Knowledge of the 2014 Education Policy Guidelines in Rukwa Region in Tanzania}

\author{
Apolinary Kaswala Ndasi \\ Lecturer, Department of Education Foundations, \\ Archbishop, Mihayo University College of Tabora (AMUCTA), Tanzania
}

\begin{abstract}
:
The study sought to establish parents' understanding of the education policy guidelines that guided their involvement in ward secondary schools in Rukwa Region. The implementation of the 2014 Education Policy had raised questions and debate on the parents' knowledge of the guidelines. Two research questions and two hypotheses guided this study. It employed concurrent mixed method design. Participants included heads of ward schools, chairpersons of school governing boards and parents having children in ward schools in Rukwa Region. The sample comprised 280 participants. Descriptive and inferential statistics were used to analyse quantitative data (by SPSS version 22) that were presented in tables. Thematic analysis was used to analyse qualitative data which were presented through quotations and paraphrasing. Findings indicated that majority of the parents in Rukwa Region were aware of the policy guidelines but did not implement it proportionately. As a result of that, some parents' participation in the implementation of the education policy varied pending their understanding of the guidelines. School location had no significant influence on the scores of the heads of schools on parents' knowledge of the education policy guidelines. Work experience of school heads had significant effect on their scores on parents' knowledge of the guidelines contrary to education level and school location that had no significant effect. The study concludes that parental involvement in the education policy implementation in Rukwa region was successful only at the communication stage but had average success at implementation stage. The study recommends that concerted efforts should be made by relevant education stakeholders to mobilize parents to actively play their role in the implementation of the education policy.
\end{abstract}

Keywords: Guidelines, implementation, knowledge, parents, policy

\section{Background to the Problem}

Though they are important educational stakeholders with a crucial role to play in implementing educational policies and influencing school running in general (Heystek, 2003), for them to adequately play their role, depends on their awareness and knowledge of what they are required to do, among others (Heystek, 2011, Tesha, 2012, Kiilu and Mugambi,2019). When parents are informed in school matters and are given relevant opportunities, they do play their roles in improving education in schools (Ngalawa, Simmt \& Glanfiel, 2015). However, the extent of parental involvement in the management of schools in Tanzania, like in many other countries, has been a persistent challenge over the years. One of the factors of the low-level parental involvement in schools' issues in Tanzania is their lack of knowledge of the existing education policies and directives (Magava, 2015, Kalolo, 2016). Magava's (2015) study showed that universal primary education did not achieve its objectives due to lack of support from the grassroots, as parents did not participate in the formulation and implementation of the policy and so were unaware of what was taking place in schools. Tarimo (1996) had earlier pointed out that the policy of education for self-reliance failed for similar reasons. This had, for a long time, raised many serious concerns among the stakeholders on the need to enhance parental participation in schools for improvement in education (Bernard, 2004; Focus, 2010; Magava, 2015, Kalolo, 2016). One of the needs was making parents fully aware of educational plans.

Nevertheless, the government of Tanzania was aware of this fact and had made several attempts to allay the said challenge. One of the interventions was the establishment of secondary school governing boards (SGBs) through the Education Act Number 25 of 1978 for the purpose of involving parents and communities in the governance of secondary schools in the country (URT, 1978; 1995). Since then, SGBs have been mandated to oversee effective governance of secondary schools in Tanzania that includes effective parental involvement (URT, 1978, 1995, 2002, $2015 \mathrm{a} ; 2016 \mathrm{~b}$ ). The parents take part in school management through School Management Teams - SMTs (URT, 2004; 2015) and parents' meetings - PMs (URT, 2015 a; 2016 a). 
SGBs were established for the purpose of managing the schools in terms of planning for development, budget control, provision of relevant education and for involving communities and parents in schools, whom the former education system had excluded. In her intent to include all the stakeholders in managing education, the government of Tanzania strengthened SGBs through the Education Policy of 1995 to address parents' concerns and enhance community and parental participation in running secondary schools (URT, 1995, Cap 4.3.4 -5). Despite those efforts, the issue persisted as parents were not fully involved in managing schools.

Furthermore, decentralization by devolution in 2004 in the Secondary Education Development Programme (SEDP) called for the establishment of ward (community secondary) schools (URT, 2004). SEDP directed communities to construct school buildings up to lintel level and the government to complete them and employ teachers for the schools. Besides this laudable partnership that resulted in significant expansion of ward (community secondary) schools (URT, 2004), the schools performed poorly in education as both parties seemed not to adequately play their roles (Komba \& Makwinya, 2014). It was unknown why this scenario emerged.

The Team Review of Primary Education Development Programme (PEDP) I and SEDP I reported that the topdown directives in the education programmes in Tanzania undermined the competences and empowerment of school committees in the management and use of funds allocated to schools (Munishi, 2014; URT, 2014, 2016 a). This was a logistically challenging bureaucracy of centralism that hindered effective implementation of the programme. School committees that were supposed to be constituted by parents were reduced to toothless entities instead of becoming enabling supportive systems.

Parents and other members of communities did not know what they were to do next after they built the schools. They did not know what was going on in the schools (Focus, 2010; Maendaenda, 2010). This created the impression that parents and communities remained stranded as regards their schools' management. This must have contributed to the reported poor academic performance. Whether the guidelines of the 2014 education and training policy were then known to the parents remained unclear.

Therefore, the government commitment to improve parental involvement through the 1995 Education and Training Policy and subsequently decentralization by devolution in 2004 had not decisively addressed the challenge of parental participation. Whether the 2014 education policy made a significant improvement in the knowledge of the guidelines among parents was equally not known.

At a practical level, some ward school heads involved parents in decision making while others did not. Whereas some studies reported high parental involvement in the governance of the schools (Salema, 2009; Fanuel, 2015; Ngalawa, Glanfield, \& Simmt, 2015), others indicated low or lack of their involvement (Matekere, 2003; Bernard, 2004; Kalolo, 2016) and others revealed mixed findings such as Makenya (2013) who reported that parents participated in School Governing Boards (SGBs) and linked others to schools. However, a quarter $(25.4 \%)$ of the participants of the study indicated that parents were reluctant to be involved in school activities as they were not aware of its importance in school management. Whether parents in Rukwa region were now clearly informed on the provision of circular number 3 of 2016 was not known.

As an intervention strategy, the government of Tanzania released the Education and Training Policy in 2014 as one of the aims put in place to address the said challenges. The 2014 Education and Training Policy, through Circular Number 3 of 2016, and procedure for voluntary contributions in schools (URT, 2016 a), amplified parental involvement in schools in the country. For the first time in the history of education in Tanzania, the government widened the roles of parents in decision-making and coming up with resolutions in all public schools for ensuring accountability therein.

The Fees Free Education Policy of 2014 intended to involve parents more in schools. It commissioned parents to play more active roles such as holding the school management to account in case they contravened the education policy, ensuring legitimation of decisions in school administration, partaking in major resolutions in all public schools and become the initiators of voluntary contributions to solve educational challenges in the schools. The circular was also meant to empower parents to reprimand and report the malpractices in the implementation of fees free basic education policy of 2014 which focused on education leadership, supervision and management that are relevant and accountable (URT, 2014). The section reads, 'Parents/guardians shall have the following responsibilities: to reprimand and to report to relevant authority regarding the behaviours that are contrary to fees free basic education' (URT, 2016, No. 3.10, section 5).

These were new responsibilities entrusted to parents by the new policy approaches. However, whether the parents were aware of the guidelines and were willing to assume their roles was not known. Thus, stakeholders were involved in the debate on the implementation of the 2014 education policy. Some held the view that parents were then more aware of what was required of them and were actively involved while others believed that they were no longer involved in their schools' affairs following the fees free education policy (Siyame, 2016; Hakielimu, 2017). It was unclear whether the parents were well-informed on what the policy required them to do. This view is echoed by Mualuko and Limukii (2012) who reported on parents' lack of clear understanding of fees free education policy and that it hindered their participation in the policy implementation in Kenya.

To further clarify the 2014 Education Policy, the government of Tanzania, through the Ministry of Education, Science and Technology, released circular number 6 on $10^{\text {th }}$ December 2015 with guidelines on the implementation of the education policy, including parents' involvement aspect. However, the circular created some confusion and misunderstanding as it was not specific on the areas which parents were to participate in decision-making and excluded other members of communities (Siyame, 2016; Ismail, 2017; Hakielimu, 2017).

The government issued yet another circular number 3 (circular 3) on 25 May, 2016 clarifying the community's/parents' participation in decisions and resolutions made in schools. It even included community members as they were not covered in the former circular. To this effect, circular number 3 was more elaborate, clear and could be 
understood. The government made additional efforts to clarify the circular for its smooth implementation (Chawe, 2017). Nonetheless, whether those clarifications were clear to parents in Katavi Region or attracted more parental involvement was unknown.

The literature that has been reviewed in this study indicate that Rukwa Region faced a number of educational challenges that were associated with parents and the local community. They included the members local community not valuing education, lack of formal education among most parents, lack of awareness of education and lack of cooperation between parents and educators, among others (Ndasi, 2003; Mhegera, 2011; Nyandwi, 2014; Mshani, 2015; Siyame, 2016; Yassin, 2017).

Such challenges positioned Rukwa region among the regions in Tanzania whose education standards was poor. Some parents colluded with their children to drop from schools and secure jobs in different economic sectors (Mhegera, 2011; Siyame, 2016 b). There were cases where parents and community members even assaulted teachers and rejected offers for discussions with relevant education authorities (Yassin, 2017). Some other parents threatened teachers when they made follow-up of their truant children (Mshani, 2015). These issues raised crucial questions on parents' knowledge and understanding of the education policy guidelines and their participation in the implementation process in the schools in Rukwa Region.

This study, therefore, was propelled by the prevailing issues in the region; hence, it sought to examine parents' knowledge of the 2014 education policy guidelines and its role on their involvement in the implementation of the policy in ward schools in Rukwa region. Its aim was to determine whether the new circular that seemed more elaborate (Hakielimu, 2017) made any improvement in parents' knowledge, understanding and involvement in ward schools as gauged by past experience.

\subsection{Statement of the Problem}

While parents' knowledge of and participation in implementing education policies have been seen to make significant contribution to effectiveness in running of schools (Ngalawa, Simmt and Glanfield, 2015; Kiilu and Mugambi,2019), their involvement in schools has been a persistent challenge in Tanzania (Tarimo, 1996; Komba and Makenya, 2014; Magava, 2015, Kalolo 2016). Even when the government released the 2015 education policy guidelines for more parental involvement in schools, parents seemed not to play their role as required. This raised concerns and debate among stakeholders regarding parental involvement in schools, some holding that it had improved while others maintained that it became worsened as the guidelines were not clear (Hakielimu, 2017).

Additionally, parents in Rukwa region demonstrated lack of interest in the running of the schools even after the launching the 2016 education guidelines that were more elaborate (URT, 2016 a; Hakielimu, 2017). These jeopardized policy implementation and school management effectiveness in the region. Hence, there were increasing concerns of stakeholders, who still questioned the aspect of parental involvement in schools in the region (Siyame, 2016, Yasini, 2017). Nevertheless, whether the parents knew the 2016 education policy guidelines clearly and could play their roles as stipulated in the procedures was not known while no study on the same was found. This study, therefore, examined parents' knowledge of education policy guidelines and their role in the implementation of the 2014 fees free basic education policy in Rukwa Region, Tanzania.

\subsection{Research Questions}

This study was guided by the following questions:

- Do the parents in Rukwa Region really know the 2014 Education Policy Guidelines on their involvement in schools?

- How do parents' knowledge of the 2014 Education Policy Guidelines influence their participation in its implementation in ward secondary schools in Rukwa Region?

\subsection{Research Hypotheses}

The study tested the following hypotheses:

- There is no significant difference in the school heads' mean scores on the parents' knowledge of the policy guidelines in Rukwa Region when comparing rural with urban schools'.

- Work experience and education level have no significant effect on the school heads' mean scores of parents' knowledge of the policy guidelines in Rukwa region.

\subsection{Theoretical Framework}

The study is grounded on the rational model of implementation of policies. Khan and Khandaker (2016) developed the rational model for enhancing policy implementation through five components: (i) clarity of policy goals, targets and objectives, (ii) accurate and consistent planning, (iii) clear and detailed task assignments, (iv)accurate standardization, and (v) proper monitoring.

These components apply to the policy implementation that presupposes the knowledge of it by the stakeholders. This model was applicable to our study as it examined parents' knowledge of the policy and its role on implementation as a dependent variable. The aspect of policy clarity, task assignment, standardization and proper monitoring as stated in the circular number 3 of 2016 were directly applicable to the model. Hence, the model was appropriate to be used in this study. All the five components are directly related to our study for they relate the parents' knowledge of the policy guidelines to their participation in its implementation. The study covers all the aspects and it is part of monitoring the effectiveness of the implementation of the policy. 


\subsection{Significance of the Study}

The study serves as a timely assessment of the implementation of the education policy that informs on the level of its effectiveness. It informs the stakeholders on the status of parents' role in the implementation of the education policy guidelines. It can help the policy implementers and monitors to make relevant decisions for arresting existing implementation hurdles; thereby enhancing its efficiency.

\section{Review of Related Literature}

This section has two parts, namely a review of one theory and that of empirical studies. First the theory, "The Optimal Model of Policymaking and Analysis,' is reviewed and then followed by the review of the empirical studies.

\subsection{Review of the Theory}

In this study, the Optimal Model of Policymaking and Analysis serves as the theoretical guide of this study. It was developed by Dror (1968) as the optimal policy making model for the policy of public policy-making. It has three phases of meta-policymaking, policy making and post-policy making including the feedback.

The meta-policymaking phase is for evaluating related values, situational analysis based on data, stating problems, identification and analysis of resources, designing policy making system, assigning problems and allocating resources to the relevant policy-making units. It is a pre-policy environmental and resources analysis. Phases two comprises the actual policy-making processes. They include agreements on strategies, values and basis for policy making, actual sub-allocation of resources, selection of alternatives and prioritization of values and specification of goals plus cost benefit analysis. Phase three is a policy implementation. This stage comprises communicating the policy to stakeholders, mobilization of implementers and actual implementation of the policy i.e. translating the policy goals into policy activities.

After the third phase is the assessment and evaluation of the policy - ascertaining and appraising the performance of the policy and sharing feedback to policy makers, implementers and other stakeholders for a decision on improving the policy performance. Dror (1968) insists that the assessment of a policy begins with policy implementation and continues until the policy implementation is completed.

The model is applicable to policy making and implementation to a large extent. Making environmental scan prior to policy making ensures appropriate formulation of relevant policies. More importantly is its direct applicability to this study that examined parents' knowledge of education policy guidelines and its effects on implementation process. The aspects of communicating the policy appropriately, motivating implementers, executing the policy and assessing and evaluating its performance is key to meaningful application of the policy. These aspects were relevant to this study.

Though the model assumes that it can universally apply in all circumstances; hence, constituting a weakness. Nonetheless, as it is mostly relevant to policy making and implementation, it was appropriate to this study that examines parents' knowledge of the education policy as stakeholders and how it influenced their participation in its implementation process.

\subsection{Review of Empirical Studies}

Parents' knowledge of educational policies is key for their successful implementation. When the policies are clear to parents, they are easily implemented and the contrary is true since implementation becomes a challenge. Different study designs have come up with varied findings on parental involvement in the implementation of schools' plans. The factors responsible for this variation are policy-related and parental-related (Okeke, 2014; Sumarsono, Imron Wiyono and Arifin, 2016; Albez and Ada, 2017). These subsequently lead to variations in the extent to which parents involve themselves in implementation of the plans in schools.

Parents' level of awareness of the education policies has been seen to accordingly influence their implementation process. The higher the knowledge level, the higher their participation in the implementation of education policies (LiCalsi, Ozek and Figlio, 2016; Al-Onizat, 2019; Al-Onizat, 2019). Thus, there is a correlation between parents' knowledge level of education policies and their level of participation in the implementation of the plans in schools. This has been reported in different studies.

In their regression - discontinuity designed exploratory study, LiCalsi, Ozek and Figlio (2016) reported that parents' awareness of the rules of the Florida Retention Policy that was intended to be a universal policy, were able to request an exemption for their children from that policy. Hence, parents reacted differently on policy implementation owing to different knowledge levels of the policy rules. As a result, the policy was unevenly implemented. However, it remains unknown whether there were specific policy guidelines for parents' roles that could be used to determine their knowledge.

Similarly, through a semi - experimental study, Al-Onizat (2019) examined the effectiveness of an educational programme in improving the level of knowledge of parents. The results of the study showed that the level of parents' knowledge of natural growth indicators for their children was low. Hence, the program was less effective in the implementation its guidelines. Further, the study discovered differences in the parents' knowledge level about developmental delay indicators.

Parents' full knowledge of educational programmes has been seen to be significant in playing their roles in schools and in school effectiveness. As parents get fully informed of what they are required to do in schools, their involvement therein gets scaled up and subsequently school improvement is augmented. This enhances quality education delivery due to the synergy of the school staff and parents' support (Ngalawa, Simmt and Glanfield (2015; Kiilu and Mugambi, 2019). Different study designs have come up with similar findings in this fact. 
In their descriptive survey research design, Kiilu and Mugambi (2019) investigated into status of school feeding programme policy initiatives that aimed at improving school enrolment and attendance and reducing dropout rates and low academic achievement in primary schools in Machakos County, Kenya. This descriptive survey showed that most schools implemented the programme successfully as parents played a vital role. This was a result of being fully informed on the programme and on what they were required to do. However, the study focused on the status of the programme, not directly on parents' knowledge. This aspect was a minor facet. As such it could not answer our questions. Hence, though the study informed on the performance of the education programme on parents' knowledge, it did not deal with an educational policy directly. Though a programme is also a plan, it was more of a capacity-building endeavour than the central plan or policy. Therefore, a little is known on parents' knowledge level of the policy but provided on their understanding of a training programme. Additionally, the factors responsible for the differences in parents' knowledge level of the programme remains covered.

A qualitative case study by Ngalawa, Simmt and Glanfield (2015) indicated that parents were aware of school policies and supported Kitamburo Primary School in Kilolo District - Iringa, Tanzania. They were involved in decisionmaking on issues such as retaining and motivating teachers and general cooperation with the school administration. The results indicated the school's improvement and high level of academic achievement at the primary school. As the policy guidelines were expected to bring positive changes, empirical verification was yet to be witnessed. However, the study did not examine any educational policy and or guidelines. It was based on school strategies in a particular school. It was more of a school leadership than universal education policy. It was a case study on a single primary school that may not necessarily apply to secondary schools and specifically to ward schools in an environment such as that of Rukwa Region. It remained uncertain as to whether parents in community secondary schools in Rukwa Region were fully aware of the policy guidelines or were involved in the same manner as per the education policy provisions.

While parents' knowledge of education policies amplify parental involvement in schools, the contrary applies as their lack of knowledge on the same hampers policy implementation. Parents become passive or resist the policies or stage their movement to change them (Okeke, 2014; Iimene, 2015; Scribner and Fernández, 2017; İlikandKonuk, 2019). This becomes the first hurdle to overcome so as to ensure effective parental involvement in schools.

A qualitative study by İlik and Konuk (2019) that evaluated parents' participation in Individualized Education Programs (IEP) by opinions of participants in Turkey that involved special education teachers and parents of children with special needs revealed that most parents did not know anything about IEP. It was also found that the parents were not involved in the IEP process nor invited by the school. As a result, the programme was not effectively implemented as it lacked support from the parents. Besides informing on parents' participation in the programme, the way it was communicated to parents is unknown.

Due to lack of parents' knowledge of school plans and programmes, they become hampered from being actively involved in the running of schools. A qualitative study that was conducted by Kabir and Akter (2014) to explore parental involvement in secondary schools in Bangladesh by focusing on how parents were involved in their children's education and the efforts made by schools to involve them, among others, revealed that most parents remained unaware of what was required of them in schools. This posed a challenge to the implementation of educational plans and policies. However, this study was limited to common practice of involving parents, not on any specific policy. Though there were commission ruling, they did not feature in the practice of parental involvement. Additionally, it was based on communication between parents and schools but not parents with other government authorities such as being responsive to circular letters or directives that guided parents' responsibilities in schools.

Parents' ignorance of educational policies, besides inappropriate school administration landscape, is one of the factors behind inadequate parental involvement in schools. A case study by Okeke (2014) revealed that school administrative structures blocked parents in London - UK, from being involved in the management of schools. As a result, they were unaware of how to get involved despite their readiness to get participate though there were neither elaborate involvement strategies nor national policy on parental involvement. Whether parents could be adequately involved if there were elaborate strategies cannot also be assumed. Yet, one is not sure whether the fees free basic education in the context of Tanzania made a difference on parental involvement. But then, Okeke's study being only a quantitative one, detailed views and explanations are missing. For instance, the reasons for not having an elaborated parental involvement plan are not given. This study began from the ground to the theory. It did not assess parents' knowledge of education policy and its implementation; hence, it suits only theoretical development.

Lack of knowledge of the education policy and perceiving the policy to be unrealistic have been seen to be inhibitive of active parental participation in the implementation of education policies. In his qualitative study on perceptions of teachers and parents regarding the implementation of the education sector policy for the prevention and management of learner pregnancy in Oshigambo inspection circuit in Namibia, Iimene (2015) found that some parents had no knowledge of the policy while others perceived it to be unrealistic. Hence, they were reluctant to partake in its implementation. In this regard, parents' knowledge applied to both their lack of understanding and rejection of the policy. Whether the same could apply in the implementation of a fees free education policy in Rukwa region was yet to be established.

What was reported in other countries regarding the clarity of educational policies seemed to take place in Tanzania in some aspects. In a case study, Zahara (2014) investigated into the factors that hindered effective parental involvement in public primary schools in Kinondoni Municipality, Tanzania. The findings revealed, among others, that the government was not open in its policy on parental involvement in primary schools. Furthermore, the government's directives confused both head teachers and parents because they were not clear on parental involvement in schools. Nonetheless, the study did not specify the area of the policy that was not clear to parents and the school management. It 
did not investigate a particular government directive on parental involvement. Whether the 2014 education policy guidelines allayed such challenges was, however, unknown.

Besides parents' knowledge as a determinant of their involvement in schools, the education policies and other frameworks count on the same. In some cases, the policies are either not realistic or unfriendly to parents. As such they become inhibitive of parental understanding and involvement in schools (Komba \& Makwinya, 2014; Kalolo, 2016; Fernández and Scribner, 2018; Welton and Freelon, 2018).

At other times, educational objectives articulated via the policies might not bear fruits if they are not well planned and implemented. Bertrand and Rodela (2018) analysed the social justice educational leadership field, underlining the leadership of youth, parents and community in educational leadership publications. The analysis indicated that many models of parental involvement were insensitive to marginalization (cultural racism). There was under consideration of structural racism and other forms of systemic inequity in education. The analysis further indicated that the power dynamics and relationships among educators, parents and the community had not fundamentally changed. Thus, even though this approach involved a critical consideration of racism and other forms of inequity, possibilities for transformative agency were constrained. The findings from Bertrand and Rodela's study showed that the strategies did not address the issue of marginalization to parents. Hence, the question on whether parents in Rukwa region knew the 2014 education policy guidelines and whether it scaled up their involvement in schools was yet to be explored.

The balance of power in educational policies has been seen to be vital in parents' roles in school leadership. However, this has been a challenge to many school administrators. Rodela and Bertrand (2018) reported that parents were not given relevant stake in school plans. The educational policies excluded and marginalized parents and other stakeholders. They recommended that parents and other stakeholders be given wider stake in equity reforms for school improvement plans within the school administration context. They insisted that there should be a balance of power among stakeholders that include parents.

Though the authors underscore the importance of parents in school improvement policies, they remain indifferent on the provision of the policy on the role of parents. Over and above, the study does not report directly on whether parents knew the plans of school improvement in the context of equity reforms in schools and whether they were enlightened on their exclusion.

In some extreme cases, parents resist education policies when they find them not relevant to education in schools. As such their implementation becomes a challenge (Fernández and López, 2017; Scribner and Fernández, 2017; Welton and Freelon, 2018).

Through a critical qualitative study, Scribner and Fernández (2017) explored the organizational politics in cases where immigrant Latina parents were supported to organize their movements within a school space for examining the consequences of these positions on their constituency within the school. It was revealed that Latina parents had concerns with immigration reforms and so did not cooperate with the policy. The immigration policy included getting fingerprinted as a condition of involvement in schools. Parents' involvement was affected by anti-immigrant policies and sentiments. The policy was, therefore, inhibitive of parental involvement as its marginalized immigrant parents. In this regard, the parents knew the policy but were against it. Hence, parents' knowledge of the education policy had negative consequences on the implementation of the plan. However, whether the fees free basic education policy in Tanzania made changes in Rukwa region could not be taken for granted as no study had been conducted on this matter.

In their case study, Fernández and López (2017) reported that the Latina parents resisted the anti-immigration policies and hindered their implementation. The study further indicated an imbalance of power dynamics in school involvement that was inhibitive of parental involvement as the Latina parents were being marginalized by the said policies. This resulted in a movement that advocated for reforms of schools by Latina parents. In such a case, the policy was inhibitive of parental involvement despite the policy provisions being clear to them. Nevertheless, whether the 2014 education policy guidelines in Tanzania were understood or positively perceived by parents in terms of providing more space for parental involvement in schools in Rukwa region or it scaled up their involvement was yet to be established.

Similar findings in education policy analysis by Welton and Freelon (2018) were uncovered. The researchers examined cases of school closure policy in the South Side of Chicago, which was a predominately working-class African American community. The policy provided that the schools that were underperforming in terms of declining student enrolments, repeated poor academic performance, budget limitations and competition from other school choices such as private schools, charters, magnet programs and selective public schools should be closed. The study employed a mixed methods design using interviews, observations, and document analysis. Findings from the study revealed parents' strong resistance to the policy; hence, its implementation was a difficult process. Though the study had informed on parents' reactions against the school closure policy, it remains silent on whether parents were given specific roles to policy in the policy. It also remains unknown on whether parents had clear policy guidelines that directed them on the same. Even their knowledge and understanding of the policy is not clearly elaborated in the study.

Lack of clear education policies affects both teachers and parents in education processes. A study by Andrews (2018) revealed that absence of clear written policy on homework tasks to students made it difficult for teachers and parents to know exactly how to go about home assignments in class. The teachers assigned learners assignments though there was no any specific policy provision that governed it. Worse, illiterate parents could not assist their children to do them at home. While the study informs us on the importance of putting in place a clear policy on assisting children with homework-based assignments by parents, it remained silent on their involvement in the policy at schools.

At times parents need to be free to initiate some practices in education so as to play their role based on what they think and believe is important. Fernández and Scribner (2018) analyzed how a Latina parent group and parent leaders activated and nurtured community cultural wealth and uncovered that the parent-initiated and parent-led groups 
created and fostered a space where community cultural wealth was acknowledged and valued within the institution. As Latina parents learned more about the new systems (policies) that they had to traverse on a daily basis, they coped with the policies or structures. As a result, some challenges between schools and parents were addressed through Latina Parents Organization (LPO) leaders' negotiations of the inherent tension that emerged between LPO and school officials when a new parent organization was established at the school. Parents, through their active work in LPO, emerged and positioned themselves as educational leaders within the school and community. All these were made possible as parents were knowledgeable and understood the policies of education and played their roles adequately.

However, it was revealed also that Latina parents resisted the plans to merge their organization with Parents Teachers Association (PTA) as they felt it would cover their identity and their interests. In this regard, the Latina parents knew the policies but did not accept all the guidelines. Whether parents in Rukwa Region knew and believed that the 2014 educational policy guidelines satisfactorily provided space for their involvement in schools was not known. It was unknown also whether the guidelines enhanced parents' cooperation with the school administration in the region.

Training of parents on education policies or programmes do contribute significantly to parents' knowledge and their participation in the implementation of education plans in schools (Sunardi, Maryadi, \&Sugini, 2014; Araque, Wietstock, Cova, and Zepeda, 2017; Bertrand, Freelon\& Rogers, 2018).

In a quasi-experimental research with a pre-test post-test design, Sunardi, Maryadi, \&Sugini (2014) conducted an investigation on the effectiveness of a two-day inclusion workshop on teachers' attitudes, understanding and competence in inclusive education in the Wonogiri District, in 25 sub-districts in Indonesia. Participants included 50 parents and 50 teachers from 25 primary schools. Findings indicated that parents' positive attitude towards the policy of inclusive education was improved after the workshop. This carries the impression that the training made parents more aware of the inclusive education policy and their attitudes became more positive towards the policy. Nonetheless, there was no evidence that the fees free basic education policy was well communicated to all parents and was clearly known and understood for them to actively participate to implement it in the schools in Rukwa Region.

Similar findings were reported in an experimental pilot study by Araque, Wietstock, Cova, and Zepeda (2017) when they examined the 'Impact of Latino Parent Engagement on Student Academic Achievement'. The study examined the impact of the Ten Education Commandments for Parents program. The aspects focused on (1) new immigrant Latino parents' knowledge of the U.S.A public education system, (2) parent engagement, and (3) their children's academic achievement. Parents in the experimental group $(n=68)$ participated in the Ten Education Commandments for Parents workshop sessions and completed pre- and post - tests to assess differences in their perceptions and knowledge of parent engagement before and after attending the program.

Results from the study showed positive variance of parent behaviour and knowledge as a result of the training sessions. Hence, it was a beneficial program. The great majority of parents said that they were no longer as intimidated with the education system and that they then had a better understanding about their roles when helping their children. Generally, the parents explained that improving their knowledge on how the schools were structured and operated, how to calculate a GPA, and how to access college opportunities empowered and reenergized them to be more active in helping their children at home. By improving parents' skills and knowledge about the education system, their sense of efficacy and commitment to continue learning was enhanced and this led to the parents seeking additional opportunities to increase their knowledge and engagement of the educational system.

The study findings were crucial in providing insight into the training of parents on educational policy and how it impacted on their knowledge and involvement in schools. Whether the same applied in the implementation of the 2014 educational policy guidelines in Rukwa Region was yet to be established. It was further unclear whether the Rukwa parents knew and understood the 2014 educational policy guidelines when compared to the Latino ones.

The effectiveness of training parents on educational policies and on the paradigm of the education system was reported also by Bertrand, Freelon \& Rogers (2018), whose study revealed that parents could shape state and local education policies after they were exposed to policy guidelines through workshops in schools. In this regard, parents become fellow leaders in education as they become active participants in educational decision making in line with the provisions of educational policies. However, what was being experienced on the preparation of parents for the implementation of the 2014 education policy in Rukwa Region was unknown.

In Tanzania, the legal framework had been a challenge to parents' knowledge and involvement in schools (Komba \& Makwinya, 2014; Kalolo, 2016). In most cases, parents are not adequately involved in schools due to being non-members of the major decision-making bodies. Sometimes they remained uninformed of what was required of them or what was going on in the schools (URT, 1995, 2001; 2014). Whether the 2016 circular guidelines were made clear and friendly to parents in Rukwa Region to make them active supporters of schools was unclear.

The reviewed studies indicate that parents' involvement was generally on a low extent in the respective countries (Zahara, 2014; Okeke, 2012; Olayiwola and Alabi. 2015). Only a few studies such as that by Sumarsono et al. (2016) in Indonesia and Ngalawa et al. (2015) in Kitamburo - Iringa, Tanzania, reported a larger extent of parental involvement in schools. None of the studies addressed parents' knowledge of the 2016 policy guidelines and their involvement in the policy's implementation. Evidence was lacking on whether the education policy guidelines introduced had made a difference on parental involvement in schools in Tanzania. 


\section{Research Methodology}

\subsection{Research Approaches}

This study employed both qualitative and quantitative approaches. While quantitative approach focuses on counts and measurements (numbers/quantities), qualitative approach focuses on meanings, concepts, definitions, characteristics, symbols, and descriptions realities (Creswell 2014, Johnson and Christensen, 2017). The application of the two approaches was propelled by the early stated assumption that the combination of the two worldviews provide a better understanding of the research problem and its solution. The two could decisively answer the research questions and address the hypotheses formulated in this study.

\subsection{Research Design}

This study employed concurrent parallel mixed research design. This design involves collecting both, qualitative and quantitative data at the same time in a single visit to the research site, while giving equal weight to both types of data. Both types of data were collected concurrently and qualitative data were compared to quantitative data for meaningful interpretation. Creswell (2014) has asserted that mixed methods procedures can be employed at data collection stage where qualitative and quantitative data are simultaneously collected.

The design was preferred for enhancing validity and reliability of the study through triangulation. The two types of methods strengthen each other and minimise their weaknesses (Punch, 2009; Ary et al. 2010). Therefore, qualitative data were used to compare and to extend the details of the quantitative data for decisive answering of the research problem. The researcher collected both types of data concurrently but analysed them separately. The results were compared for confirmation or reliability of both types of data. It is also less time consuming, hence it was more appropriate to the study.

\subsection{Target Population}

According to Rukwa Regional Education Officer's (REO's) response on $8^{\text {th }}$ March 2017, Rukwa region had a total population of 1, 192, 373 (578, 431 males and 613, 942 females). There were 70 ward secondary schools and 1,447 teachers distributed in four administrative districts. Table1 presents the schools and teachers' distribution in Rukwa Region.

\begin{tabular}{|c|c|c|c|}
\hline Districts & Schools & Teachers & Population - Region \\
male $-578,431$ \\
Kalambo & 15 & 258 & female 613, 942 \\
Nkasi & 23 & 300 & \multirow{2}{*}{$1,192,373$} \\
\hline Sumbwanga - Municipality & 17 & 603 & \\
\hline Sumbawanga -Rural & 15 & 286 & \\
\hline Total & 70 & 1,447 & \\
\cline { 1 - 2 } Table 1: Distribution of Community Secondary Schools and Teachers - district wise
\end{tabular}

The target population in this study included heads of ward secondary schools (HoSSs), chairpersons of school governing boards (CSGBs) in community secondary schools and parents who had children in the schools and were responsible for their education in Rukwa Region. All ward schools in the region were targeted in this study.

The heads of schools and governing board chairpersons were responsible for implementing the education in schools (URT, 1978; URT, 1995; URT, 2015 b; URT, 2016a); hence, were considered important in the population of the study. Parents were the centre of the study in the light of the new education policy guidelines. They had been given new responsibilities by the government to cooperate with the managing teams of schools and monitor the implementation of the 2014 Education Policy (URT, 2015 b; URT, 2016a). Table 2 presents a summary of the different categories of the target population.

\begin{tabular}{|c|c|}
\hline Target Population & Number \\
\hline Chairpersons of School Governing Boards & 70 \\
\hline Heads of Ward Schools & 70 \\
\hline Parents having children in Ward Schools & 17,710 \\
\hline Total Target Population & $\mathbf{1 7 , 8 5 0}$ \\
\hline
\end{tabular}

Table 2: Categories of Target Population $(N=17,850)$

\subsection{Sample size and Sampling Procedures}

This section deals with determination and justification of the size of the study sample and the sampling techniques of different categories of participants.

\subsubsection{Sample Size}

The sample representativeness is essential and more important than its size in a study (Babbie, 2008; Cohen; Manion and Morrison, 2011). The sample size depends on the nature of the population and the needed data (Kahn and Best, 2006). It can be $10 \%$ of the population as the minimum for a descriptive study, or $20 \%$ for small populations (Gay, 1987; Gay; Mills; and Airasian, 2012). Mugenda and Mugenda (1999) proposed it using as large sample size as possible, even up to $50 \%$. A sample size of 30 participants or cases has been recommended by scholars for studies that involve 
statistical analysis (Bailey, 1994; Kahn and Best, 2006). However, Kahn and Best (2006) view samples of 30 or more cases as large samples and less than 30 as small ones.

The researcher opted to select 40 heads out of 70 HoSSs in the region. One CSGB in each of the 40 schools was included in the study. These formed $57.14 \%$ of the total population of the HoSSs and CSGBs. As for the parents, the strategies of sampling did not favour any sample estimates. The researcher decided to use the 200 parents as a reasonable number that could be used to justifiably make conclusions of the findings on this category. Thus, the sample for this study comprised280participants. It, therefore, included 40 heads of ward schools, 40 chairpersons of school governing boards (CSGBs) and 200 parents.

\subsubsection{Sampling Procedures}

Normally mixed method designs, as earlier described, use samples with different sizes and scopes (Teddlie and Tashakkori, 2009 in Cohen; Manion and Morrison, 2011). The study assumed that there were different ontological realities in the population with different understanding of the research problem. It was, epistemologically and phenomenologically assumed also that some participants had common experience and knowledge of the research problem hence they could provide information that could be generalized to the population. The researcher employed purposive sampling to select Rukwa region for the earlier stated reasons and so the four districts were automatically included in the study.

Stratified random sampling was applied to select school heads based on their location - rural and urban and then coastal and highland areas that constituted units of analysis (Creswell \& Clark, 2011; Teddlie\& Yu, 2007). Simple random sampling was applied in each category of school heads.

Convenience (opportunity/accidental) and snowball sampling techniques were employed to select parents. The techniques were used as parents were scattered in varied sites. Thus, the researcher included in the sample the parents who were available and had children enrolled in ward schools in Rukwa Region. Heads of schools and students were also requested to assist in identification for selection of the parents until a total of 200 parents were included in the sample. Snowball sampling was applied also to supplement the convenience technique. Snowball sampling is also supported by other scholars (Kombo and Tromp, 2006; Mugenda and Mugenda, 1999). Only those parents who were able to read and write in either Kiswahili or English were included in the sample.

The 40 chairpersons of school governing boards from the 40 schools were automatically included in the sample. Table 3 summarizes the target population, sampling frame plus procedures and sample size of the study.

\begin{tabular}{|c|c|c|c|}
\hline Target Population & Sampling Frame & $\begin{array}{c}\text { Sampling } \\
\text { Procedure }\end{array}$ & Sample Size \\
\hline School Heads & $\begin{array}{c}70 \text { a.[rural: i. coastal = 15; } \\
\text { ii. uplands = 38] b.[urban }= \\
17]\end{array}$ & Stratified random & 40 \\
\hline Ward Schools & 70 & Automatic & $(40)$ \\
\hline Board Chairpersons & 70 & Automatic & 40 \\
\hline Parents & 10,120 & $\begin{array}{c}\text { Snowball and } \\
\text { Convenience }\end{array}$ & 200 \\
\hline Total & 17,710 & & 280 \\
\hline
\end{tabular}

Table 3: Sampling Matrix

\subsection{Pilot Testing of the Instruments}

Besides the experts' validation, the instruments were pilot-tested to determine their performance ability and applicability (Creswell, 2009; Gall, Gall \& Borg, 2007). Pilot-testing was conducted in four schools that were not included in the sample of the main study. Pilot testing of the questionnaires was made to 4 HoSSs, 4 CSGBs and 30 parents to enable the researcher to check for language clarity, relevance of the research questions, comprehensibility and spacing for responses. Pilot-testing of the interview guide was done to 4 HoSSs. Relevant corrections were made to improve the instruments.

\subsection{Validity and Reliability of Research Instruments/Results}

To ensure relevant results and drawing meaningful conclusions of the study, reliability (consistent interpretation) of the findings produced by the instruments (Field, 2009) and validity of the instruments were ascertained. Reliability of each type of study results was established based on the relevant procedures and both types of data were compared to enhance deeper understanding in this mixed method design. Reliability of quantitative findings was established using Cronbach alpha test on the results from scales (Creswell, 2014). Cronbach alpha test, which is appropriate for computing data on scales (Field, 2013), was used through statistical package for social sciences (SPSS) version 22. The test of reliability of the findings from parents' responses, in the scale, indicated .90 and those from the heads of schools showed .98. The results imply that the findings were highly reliable.

To ensure validity and reliability of qualitative data (Ary, et al. 2010), four kinds of techniques were employed. They included confirmability, credibility, dependability and transferability (Teddlie \& Yu, 2007; Kerlinger \& Lee, 2000; Krathwohl, 2009). These were meant to ensure that what was recorded or reported was what was actually taking place in the field. 
Objectivity (confirmability) of qualitative data were determined by triangulation, member checking and use of participants. No bias was entertained but honesty was observed in quotations (Krathwohl, 2009). The researcher treated all participants equally to avoid any influence or motivation. Member-checking was done with district secondary education officers and heads of schools who were interviewed (Gall, Gall and Borg, 2007; Creswell, 2014; Salema, 2014).

The consistency of the collected data (credibility) were established by prolonged interviews, member-checking, chain of evidence from different sources (source triangulation); hence, ensuring their credibility (Krathwohl, 2009; Gall; Gall and Borg, 2007). The study compared quantitative data with qualitative data to ensure their credibility. The data were in agreement to a large extent.

Reliability (dependability) of qualitative data were determined by member-checking, triangulation and prolonged interviews (Morse, Barrett, Mayan, Olson, and Spiers, 2002; Krathwohl, 2009). The researcher consistently checked the coherence of data throughout the research process (Charles \& Mertler, 2002). All the stages and components of the study (research questions, data collection procedures, analysis and interpretation of data that) were aligned to the data and were regularly checked to ensure that the results were trustworthy. These procedures-controlled reliability of the study results (Gall et al.2007; Salema, 2014).

Transferability (applicability of the findings to other contexts) (Teddlie \& Yu, 2007) was determined through aligning or matching the study results to reviewed theories and studies in other contexts and situations as evaluated in Chapter Two. The researcher matched the findings to existing body of knowledge (related literature) to establish applicability to other findings. By collecting rich data through open - ended questionnaire items and in-depth interviews, the study findings could be established to apply to other contexts or similar cases or situations as they could be captured via detailed data collection (Krathwohl, 2009).

To ensure that the instruments for collecting both qualitative and quantitative data facilitated making of meaningful interpretations (inferences) of the data from the instruments administered (Ary et al. 2010; Creswell, 2014), three levels of validating the instruments were employed. They included researcher's initial validation, experts' validation and pilot testing the instruments. One Kiswahili expert was involved in translating English into Kiswahili for the questionnaire for parents. Pilot testing of the instruments was done to test their validity in the real world.

\subsection{Data Collection Procedures}

The researcher obtained a letter of introduction from the Rukwa Regional Administrative Secretary (RAS), who referred the researcher to the Regional Education Officer (REO) and then he was introduced to the District Secondary Education Officers (DSEOs). From there the researcher got permission to visit the sampled schools and participants, made appointments and met the selected participants for data collection. The researcher administered the research instruments by himself. A cell phone was used for voice recording and a note book for note taking when interviewing the participants.

\subsection{Data Analysis Procedures}

The data were analysed through examining, deducing and interpreting the information (Kombo and Tromp, 2006). It included computing descriptive and inferential statistics for quantitative data using the SPSS and summarising, identifying and categorising themes and explaining, paraphrasing and quotations of qualitative data (Kombo and Tromp, 2006; Gall et al., 2007).

Quantitative data such as scores of participants' preliminary information and items such as yes/no scales were analyzed by descriptive statistics using SPSS version 22. In describing the intensity or occurrences, descriptive statistics, namely frequencies and percentages were used. Qualitative data such as opinions, views, perceptions, suggestions and explanations were analysed thematically by creating categories of themes, summarizations, synthesising and determining trends of the responses (Mugenda and Mugenda, 1999; Kombo and Tromp, 2006; Gall et al., 2007). Where recording was applied, data processing and transcriptions of recorded responses and transforming body language and actions into field notes was involved in data analysis. The data were then summarised into themes and presented by paraphrasing, direct quotations, explanations and thereafter interpreted by ascribing meaning to them (Lukwata et al. 2014).

\subsection{Research Ethical Consideration}

In the whole process of the study, the researcher adhered to research ethical provisions. All the sources used in this study have been acknowledged in form of - in-text citations and included in the references list. All the formal procedures were adhered to as described in data collection procedures. Participants were requested to make free consent to participate in the study. Note-taking was used to collect data when participants opted for it instead of interview. Participants' privacy and suggestions were observed and respected accordingly. The information collected from participants were kept confidential. Only the information collected from participants were included in the study and were objectively analysed and reported.

\section{Findings and Discussions}

The section covers the areas of return rates of the instruments, demographic characteristics of participants, parents' knowledge of the education policy guidelines and its effects on the implementation of the policy in Rukwa Region.

\subsection{Return Rate of Instruments}

A total of 252 participants participated in the study. The interview guide was administered to heads of ward school (HSSs). Questionnaires were administered to heads of secondary schools, chairpersons of ward school governing boards (CSGBs) and to parents. The summary of return rates of the instruments is indicated in Table 4. 


\begin{tabular}{|c|c|c|c|c|}
\hline Participants & Instruments administered & Returned & Completed & Incomplete \\
\hline HSSs & 40 Questionnaires & $32(80 \%)$ & $31(96.87 \%)$ & $1(3.13 \%)$ \\
& Interview guide & $21(65.63 \%)$ & $21(65.63 \%)$ & $0(0.0 \%)$ \\
\hline CSGBs & 40 Questionnaires & $20(50 \%)$ & $16(80 \%)$ & $4(20 \%)$ \\
\hline Parents & 200 Questionnaires & $200(100 \%)$ & $167(83.5 \%)$ & $33(16.5 \%)$ \\
\hline
\end{tabular}

Data in Table 4 show that $32(80 \%)$ heads of ward schools responded to and returned the questionnaires. Out of these school heads, 21 (65.6\%) were also interviewed besides responding to the questionnaires. Other participants, who returned the questionnaires, included 20 (50\%) chairpersons of ward school governing boards and $200(100 \%)$ parents. This forms ninety percent (90\%) of the participants who retuned the instruments. $28(10 \%)$ individuals from the selected sample did not return the questionnaires.

There were some questionnaires that were not completely filled in by participants. They included 1 (3.13\%) from a head of ward school, 33 (16.5\%) from parents and 4 (20\%) from the chairpersons of school governing boards.

\subsection{Demographic Characteristics of Participants}

This second section of the first part of the chapter presents demographic information of participants of the study. Table 5 summarises the demographic information of the participants.

\begin{tabular}{|c|c|}
\hline Participants & Demographic Features \\
\hline HSSs & Sex, work experience, education level, and geographical area of work \\
\hline CSGBs & Office experience, education level and geographical area of duty \\
\hline Parents & Relationship with students and level of education \\
\hline
\end{tabular}

Table 5: Demographic Characteristics of Participants

The demographic information of chairpersons of ward school governing boards focused on three features namely office experience, education level and geographical area of duty. School heads' demographic information was based on four aspects that included sex, education level, work experience and school geographical location. Parents' demographical information focused on two features which were their relationship with students and level of education.

\subsubsection{Demographic Information of CSGBs}

The demographic characteristics of the chairpersons of schools' governing boards focused on the same variables of geographical area, experience in offices and education level. Their demographic characteristics are summarised in Table 6.

\begin{tabular}{|c|c|c|c|}
\hline Variable & Levels & Frequency & Percentage \\
\hline Geographical Area & Rural upland & 9 & 45 \\
\hline & Rural coastal & 5 & 25 \\
\hline & Municipality & 6 & 30 \\
\hline Office Experience & 1 to 4 years & 16 & 20 \\
\hline Education Level & 5 years or above & 4 & 25 \\
\hline & Primary & 5 & 55 \\
\hline & Secondary & 11 & 5 \\
\hline & Diploma & 1 & 10 \\
\hline
\end{tabular}

Table 6: Demographic Characteristics of Ward School Boards Chairpersons (N=20)

Data in Table 6 revealed that $9(45 \%)$ of the participants were in rural upland, $6(30 \%)$ in municipality and 5 $(25 \%)$ in the rural coastal schools. More than three quarters (80\%) had office experience of between 1 and 4 years and less than quarter (20\%) had experience from 5 years and above. As regards their education level, 5 (25\%) had primary level of education, 11 (55\%) secondary level, 2 (10\%) were graduates and $1(5 \%)$ had a diploma education level.

CSGBs education features might have resulted from lack of education opportunities in the region or due to the local community not valuing education as a quarter percent had primary school level while more than a half had secondary school level. This could influence the level of parental awareness of education and involvement in schools as these are their representatives in the management of the institutions.

\subsubsection{Demographic Characteristics of Heads of Ward Secondary Schools}

The demo-graphic information of the school heads comprised the features of sex, education level, school location (working area) and work experience. Their demographic information from questionnaires is presented in Table 4.4. 


\begin{tabular}{|c|c|c|c|}
\hline \multicolumn{2}{|c|}{ Variable } & Frequency & Percentage \\
\hline \multirow{2}{*}{ Sex } & Male & 27 & 84.4 \\
\cline { 2 - 4 } & female & 5 & 15.6 \\
\hline \multicolumn{2}{|c|}{ Education level } & 8 & 25.0 \\
\hline \multirow{3}{*}{ Work experience } & Diploma & 21 & 65.6 \\
\cline { 2 - 4 } & Bachelor & 3 & 9.4 \\
\hline & $1-4$ years & 18 & 56.25 \\
\hline & $\begin{array}{c}\text { 5 years and } \\
\text { above }\end{array}$ & 14 & 43.75 \\
\hline \multicolumn{2}{|c|}{ School location } & & \\
\hline & Municipality & 9 & 28.1 \\
\cline { 2 - 4 } & Rural Coastal & 8 & 25.0 \\
\cline { 2 - 4 } & Rural upland & 15 & 46.9 \\
\cline { 2 - 4 } & Total & 32 & 100.0 \\
\hline
\end{tabular}

Table 7: Demographic Characteristics of Ward School Heads $(N=32)$

Based on the sex of the heads of schools as Table 4.4 shows, 27 (84.4\%) were males and 5 (15.6\%) were females. $8(25 \%)$ heads of schools held a diploma in education, while $21(65.6 \%)$ were bachelor degree holders and $3(9.4 \%)$ had a master degree in education. More than half (56.25\%) of the participants had working experience ranging from one to four years and less than half (43.75\%) had five years and above. The majority of the participants $(46.9 \%)$ headed schools in rural uplands. More than quarter (28.1\%) of the school heads were in Sumbawanga Municipal Council and a quarter (25\%) worked in coastal zones in rural areas.

Three quarters of the school heads were graduates with sufficient work experience; so, they could provide reliable information. The female heads of schools were less than a quarter (15.6\%) of the total number of school heads. This could have resulted from gender-related challenges in the history of education in the region and the country in general since women had been denied access to education in many societies in Africa (Coombs, 1985; Vavrus, 2003). Only recently, women have been given the right to education and so probably a few of them had qualities to head schools.

\subsubsection{Demographic Information of Parents}

The demographic characteristics of parents were delimited to their relationship with the students (either real parent or guardian) and education level. Their demographic characteristics are presented in Table 8.

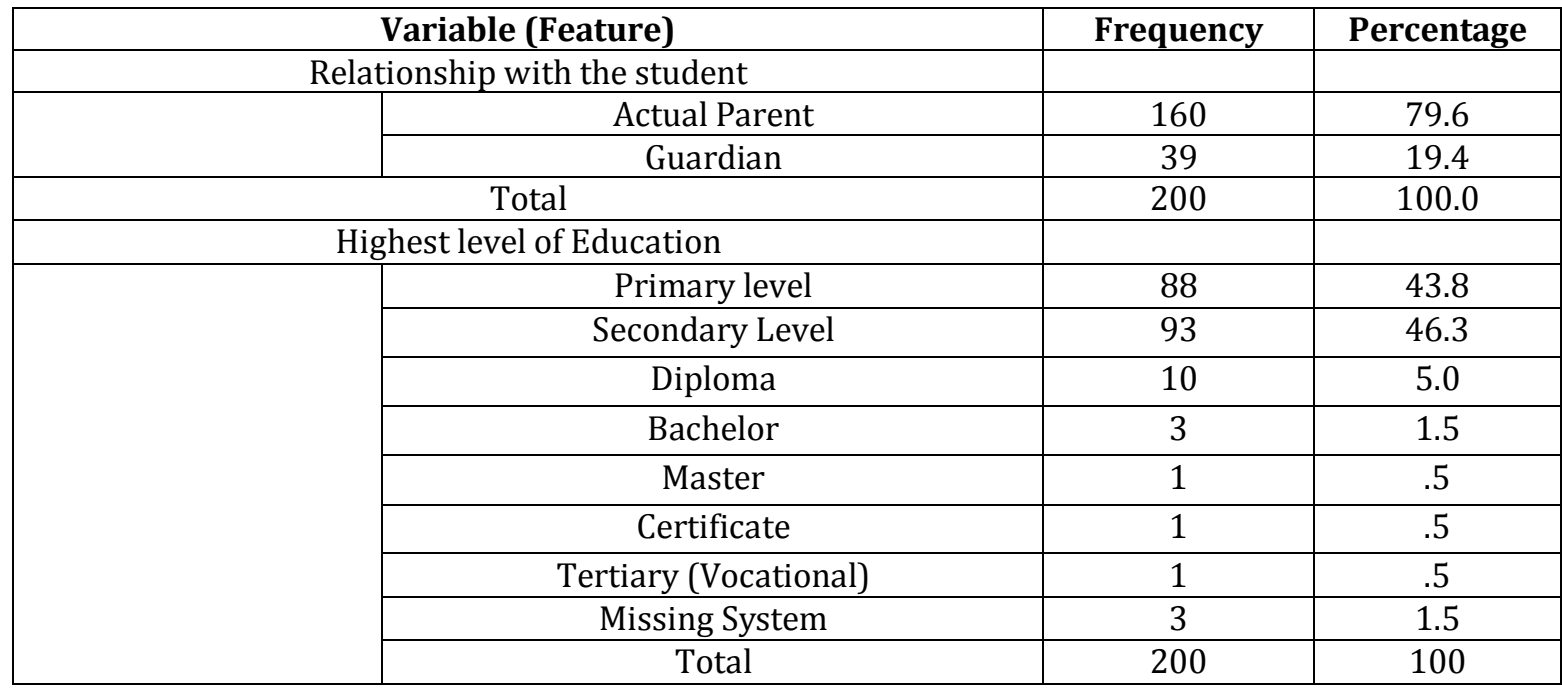

Table 8: Demographic Characteristics of Parents $(n=200)$

Findings in Table 8 disclose that, out of the 200 participants, 169 (79.6\%) were the biological parents while 39 (19.4\%) were guardian parents. 88 (43.8\%) parents had primary education level, $93(46.3 \%)$, secondary education level, $10(5.0 \%)$ had a diploma in education, $3(1.5 \%)$ were bachelor holders, $1(.5 \%)$ had a master degree and $1(.5 \%)$ had certificate and the same proportion had certificate plus vocational training respectively.

As more than two thirds were actual parents, they were expected to be closely responsible for their children's education. Hence, the information which they provided were more reliable. The same applies to their education level on which it was indicated that 108 participants (54\%) had an education level ranging from secondary school to master degree levels. As such, they were expected to be knowledgeable and so their responses reliable. 


\subsection{Parents' Knowledge of the Policy Guidelines}

The first item investigated was the parents' knowledge of the education policy guidelines. Ensuring that parents know the guidelines was considered part of the implementation of the policy - at communication level. The underlying assumption to this item was that their knowledge of the guidelines could determine their involvement in their implementation in the schools. The information was obtained from the questionnaire responses from the chairpersons of school governing boards (CSGBs) and parents and from the questionnaires and interviews with heads secondary of schools (HSSs). The findings from the yes / no responses from CSGBs and parents are summarised in Table 4.6.

\begin{tabular}{|c|c|c|c|c|c|c|}
\hline \multicolumn{2}{|c|}{$\begin{array}{c}\text { CSGBs' } \\
\text { Responses }\end{array}$} & Frequency & Percentage & $\begin{array}{c}\text { Parents' } \\
\text { Responses }\end{array}$ & Frequency & Percentage \\
\hline \multirow{4}{*}{} & Yes & 13 & 65.0 & Yes & 109 & 59.56 \\
\cline { 2 - 6 } & No & 7 & 35.0 & No & 74 & 40.44 \\
\cline { 2 - 7 } & Total & 20 & 100.0 & Total & 183 & 100.0 \\
\hline
\end{tabular}

Table 9: Parents' Knowledge of the Policy Guidelines ( $N=203)$

The findings in Table 9 show that 13 (65\%) CSGBs and 109 (59.56\%) parents who participated in the study, indicated that the parents knew the education policy guidelines and 7 (35\%) CSGBs and $74(40.44 \%)$ parents indicated that they did not know them. It means that more than a half of the participants believed that parents knew the policy guidelines while more than a third were convinced that parents did not know the guidelines.

The parents' scores concurred, to a large extent, with those of the chairpersons of the school governing boards. Similar results were also reflected in the responses from the heads of schools.

The responses of heads of schools on the questionnaire indicated that, out of the 29 participants who responded to the item, more than half (58.62\%) participants indicated parents knew the guidelines and more than a third (41.38) participants indicated parents did not know the guidelines. Through structured items (no, not sure and yes) in the interview with the heads of schools, the participants gave the following responses with regards to parents' knowledge of the policy guidelines as presented in Table 10.

\begin{tabular}{|c|c|c|c|}
\hline \multicolumn{2}{|c|}{ Category of Response } & Frequency & Percent \\
\hline \multirow{4}{*}{ No } & 7 & 33.33 \\
\cline { 2 - 4 } & Not sure & 4 & 19.05 \\
\cline { 2 - 4 } & Yes & 10 & 47.62 \\
\cline { 2 - 4 } & Total & 21 & 100.00 \\
\hline
\end{tabular}

Table 10: School Heads' Responses on Parents' Knowledge of the Guidelines ( $N=21)$

The findings in Table 10 show that more than a third (47.62\%) of the participants indicated that the parents knew the policy guidelines. One third (33.33\%) of the participants indicated they did not know them while less than a quarter (19.05) showed that parents were not sure whether they knew the policy guidelines.

The findings echo the responses of parents and those of the chairpersons of school governing boards. This implies that majority of the participants believed that parents knew the education policy guidelines. It creates the impression that communication of the education policy to parents at the implementation stage was, to a large extent, successful.

In the open-ended question, the CSGBs provided details on their yes or no responses. Those who indicated that parents knew the 2014 education policy guidelines, explained that they were informed during the meetings with school management committees or in the meetings with parents or directives through students. On this aspect, one participant responded, 'Parents get communication and explanations of the education guidelines in different modes and official meetings with them'. This shows that most parents knew the guidelines of the 2014 fees free education policy.

However, some CSGBs responded that parents were not aware of the provisions of the education policy guidelines. For instance, participant wrote, 'Most parents do not know the policy guidelines as they were not well prepared earlier on the fees free education policy'.

The parents elaborated that the guidelines were not known to them. One parent wrote, 'I have not understood the guidelines of circular number 3 of the 2016'.

These findings create the impression that majority of parents knew the policy guidelines but they were not all implementing them.

The findings differ from Hakielimu (2016) report which indicated that parents were unaware in general. The difference could emanate from the long-time implementation as Hakielimu carried a study immediately after the implementation of the policy.

\subsection{Influence of Parents' Knowledge of the Guidelines on Policy Implementation}

The extent of policy implementation depends on its communication and clarity to stakeholders.

This study explored further the influence of parents' knowledge of the policy guidelines on their participation at its implementation process. The data were obtained from responses from questionnaires for parents and the CSGBs and the unstructured items on the interview with the heads of schools. 


\subsubsection{Responses from Parents}

Parents were asked to explain in detail how their knowledge of the education policy guidelines influenced their participation in its implementation. Most parents explained that they took part in the implementation of the 2014 Education Policy after they were informed about its guidelines through circular number 3 of 2016. They identified the areas in which they implemented the guidelines including providing voluntary contributions for the purchase food for their children at schools, provision of education needs and attending and implementing the resolutions regarding the 2014 fees free education policy.

Some parents saw the policy as being favourable to the low-income families and so were motivated to actively take part in its implementation. They added that the guidelines favoured the parents in general as they had reduced costs of their children's education. Parents indicated that they had understood also that it was their responsibility to play part in the implementation of the guidelines and that they had to comply with the government regulations. Some parents explained that they saw the need to support the government's efforts in the provision of education to their children.

On the merits of the police, one parent responded, "The fees free education has enabled parents with low income to send their children to schools with very little costs'. Another parent wrote, 'I participate in implementing the policy guidelines because it is my responsibility as a parent. I have children learning in our ward schools'. Equally, another parent explained, 'I am involved in the implementation of these policy guidelines because, normally, teachers assist us even when we fail to manage our children as we take them to teachers who manage them and enable them to proceed with their school. Thus, we are encouraged to motivate the teachers'.

However, some other parents were reluctant to participate in efforts to implement the policy of which they were not fully informed. They claimed that some of the challenges they encountered included being not fully aware of what the guidelines provided for, doubted the consequences of the implementation, and inconsistence of the directives of the guidelines. Some parents saw the guidelines having deficiencies that could affect the quality of education and as unrealistic.

One of the parents who were unaware of the policy issues responded, 'I have never seen the section of the policy that directs on what parents should do'. The other parent responded, 'I have never seen the said circular number 3 of 2016 that guides parents on how to take part in the implementation of the education policy'. Another parent wrote, 'I do not know in detail on what parents are supposed to do regarding the 2014 fees free education policy'. These views hindered parents from actively participating in the implementation of the education policy in Rukwa Region.

Furthermore, some parents saw the policy as having serious weaknesses. In this regard, one parent explained, 'The guidelines have serious shortages. What is spoken about fees free education does not reflect the real costs of education in schools'. Another parent wrote, 'The fees free education is inhibiting and deteriorating education in schools resulting in production of incompetent products in our society. It is not good to apply its directives'. Some other parents believed that the policy guidelines had a few challenges for them. One of them wrote, "The responsibilities of parents are hard to implement'. This accounted for the average level of its implementation.

\subsubsection{Responses from the Chairpersons of School Governing Boards (CPSGBs)}

Some of the chairpersons of the school governing boards stated that the parents were implementing the named guidelines by providing their children with the required education needs. Others responded that the parents were ignorant on policy guidelines. They added that their illiteracy and lack of awareness on matters of education stemmed from the fact that they were not properly prepared for taking part in the policy's implementation. One chairperson claimed, 'Most parents do not know the policy guidelines; therefore, the parents need some education on this matter'. Another chairperson wrote, 'Many parents do not know the guidelines for they were not prepared earlier on this exercise'. Yet another participant reported that parents had not understood the importance of follow up of their children's education.

\subsubsection{Responses from Heads of Schools}

Findings from the open-ended items in the interview with the heads of schools showed that most parents knew the policy guidelines and were actively taking part in the implementation process. One head of school said, 'Our students' parents do participate in implementing the resolutions without problems of their own'.

Contrary to this remark, some other heads of schools said that some parents were reluctant to take part in the implementation of the policy even when they were aware of what was required of them. Among the heads who had this view, is the one who said, 'Parents do agree with the guidelines but when it comes to the policy's implementation they decline to be involved'.

The findings of the study also showed that most parents knew the policy guidelines and actively participated in executing them; hence, echoing the findings of other studies such as Ngalawa, Glanfiel and Simmt, (2015) and Kiilu and Mugambi, 2019). Excluding other factors, parents can always make a significant contribution in policy implementation if they are fully informed of what it entails. Additionally, parents were comfortable that they were give room in the policy implementation and were motivated to implement it. The findings are contrary to studies such as Rodela and Bertrand (2018) who pointed out that parents felt not represented in the policies. Besides that, some aspects of the guidelines were unclear as some parents noted that, at least, they were representative to the parents in the country. Presumably they could be effectively implemented if all other factors were aligned to the policy and parents' knowledge.

However, much as majority parents knew the policy guidelines, the implementation did not match with their knowledge level. Thus, some other factors must have accounted for the mismatch. This can be attributed to inapplicable 
guidelines and their lack of clarity as some parents noted. This finding has some research backing as different reports indicate (LiCalsi, Ozek and Figlio, 2016; Al-Onizat, 2019). This has been seen to be a serious hurdle against parents' involvement in policy implementation in schools. As a result, general performance in education will decline (Lawuo, Machumu and Kimaro, 2015). Parents further remain passive participants and the objectives for their role is not achieved (Mbugua and Rarieya, 2014; Iimene, 2015). Therefore, it follows that full knowledge of the policy guidelines must be acquired by all parents for them to be able to participate in the implementation process accordingly.

Some parents seemed to resist the implementation of the education policy guidelines on the belief that they were risking the performance of education or the guidelines were hard to implement. This is also echoed by studies such as Fernández and López (2017), Scribner and Fernández (2017), Welton and Freelon, 2018). The findings indicate that there were some issues that stemmed from the policy that were inhibitive of parental involvement regardless parents' knowledge of the guidelines in Rukwa Region.

The revelation that some parents needed more knowledge on the policy is important for them to know and understand it for its effective implementation. This is supported by different studies such as Sunardi, Maryadi \& Sugini (2014); Araque, Wietstock, Cova, and Zepeda (2017); Bertrand, Freelon \& Rogers (2018). Training that is geared towards raising the parents' awareness on policy issues and their roles can allay the challenges and improve education in the region through the implementation of the policy guidelines via significant parental involvement. Thus, the findings of this study were in line with some studies though with some variations. The reasons for this could be sociological and cultural, among others.

\subsubsection{Testing of Hypothesis}

For the purpose of generalizing the findings to the population of the sampled participants (heads of schools), the researcher tested two hypotheses, namely independent t-test and one-way analysis of variance (ANOVA). In both tests, .05 significance level was used as a decision rule; that is, when $p$ value is equal to or less than .05 , the test result is significant and if $\mathrm{p}$ value is greater than .05 it is not significant.

\subsubsection{Testing Hypothesis 1}

The study conducted a $\mathrm{t}$ - test that compared the mean scores of the participants from rural and urban schools to determine if school location had influence on their responses. An independent sample - t-test model was used. The hypothesis was, 'There is no significant difference in the school heads' mean scores on the parents' knowledge of the policy guidelines in Rukwa Region when comparing rural with urban schools'. The assumptions of t-test model are: that the subjects in two groups are randomly and independently selected; the variances of the dependent variables of the two samples are equal (homogeneous); the distribution of dependent variable is approximately normal; the scores in the two samples are either interval or ratio. The t-test results are presented in Table 11.

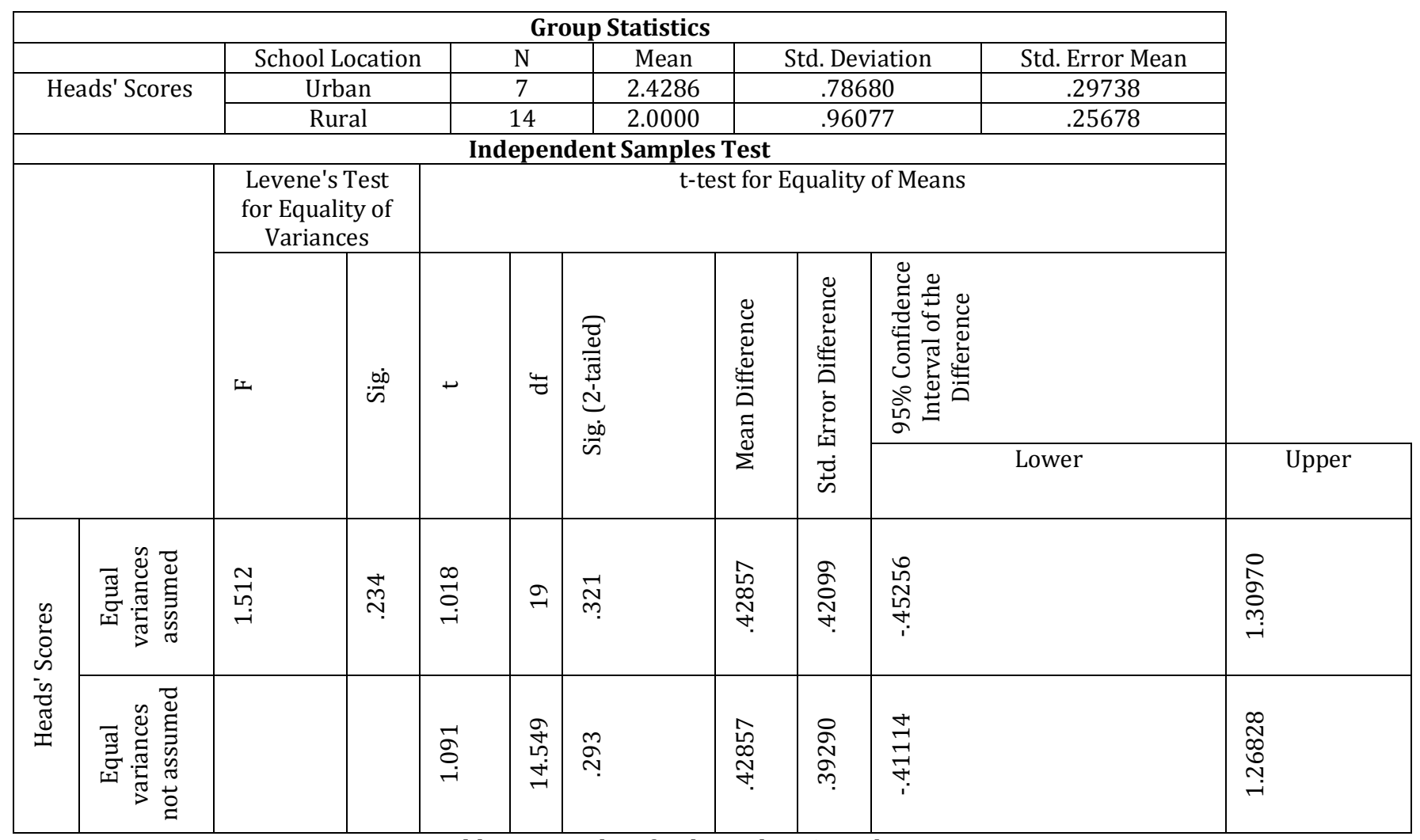

Table 11: Results of Independent Samples - T-test

The test results in Table 11 revealed a difference in the mean scores of the heads of urban schools $(\mathrm{M}=2.43, \mathrm{SD}$ $=.79)$ when compared with those of the heads of schools in rural areas $(M=2.00, S D=.96)$. However, the mean difference in the scores between the two groups of participants was not statistically significant, $\mathrm{t}(19)=1.02, \mathrm{p}=.32$. The observed 
difference in the descriptive statistics was due to random error or by chance. In this regard, the researcher failed to reject the null hypothesis and concluded that there was no statistical significant difference in the school heads' mean scores of the parents' knowledge of the policy guidelines in Rukwa Region. This implies that the participants had similar views on parents' knowledge of the education policy guidelines regardless of their work place. It means the parents had more or less the same level of understanding of the guidelines.

\subsubsection{Testing of Hypothesis 2}

The researcher conducted a test of a two-way analysis of variance (ANOVA) to determine whether work experience and education level had significant effect on the scores of the school heads on parents' knowledge of the education policy guidelines. The hypothesis stated, 'Work experience and education level have no significant effect on the school heads' mean scores of parents' knowledge of the policy guidelines in Rukwa Region'.

The assumptions of ANOVA are that: i. there is proximate normal distribution of dependent variable, homogeneity/similarity/equality of variances of dependent variable groups, the samples have been randomly selected from the population and that the dependent variable is either interval or ratio. The data were generated by assigning scores to the responses as follows: No $=1$; Not sure $=2$ and Yes $=3$. The test results are summarised in Table 12 .

\section{Work Experience}

\begin{tabular}{|c|c|c|c|c|c|c|c|}
\hline \multicolumn{8}{|c|}{ 1. Work Experience } \\
\hline \multicolumn{8}{|c|}{ Dependent Variable: Heads' Scores } \\
\hline \multirow[t]{2}{*}{ Work Experience } & \multirow[t]{2}{*}{ Mean } & \multirow{2}{*}{\begin{tabular}{|c} 
Std. \\
Error
\end{tabular}} & \multicolumn{5}{|c|}{ 95\% Confidence Interval } \\
\hline & & & \multicolumn{2}{|c|}{$\begin{array}{l}\text { Lower } \\
\text { Bound }\end{array}$} & \multicolumn{2}{|c|}{ Upper Bound } & \\
\hline 1 to 4 Years & 2.607 & .245 & \multicolumn{2}{|c|}{2.089} & \multicolumn{3}{|c|}{3.125} \\
\hline $\begin{array}{l}5 \text { Years and } \\
\text { above }\end{array}$ & 1.333 & .413 & \multicolumn{2}{|c|}{.462} & \multicolumn{3}{|c|}{2.204} \\
\hline \multicolumn{8}{|c|}{ 2. Education Level } \\
\hline \multicolumn{8}{|c|}{ Dependent Variable: Heads' Scores } \\
\hline \multirow{2}{*}{$\begin{array}{l}\text { Education } \\
\text { Level }\end{array}$} & \multirow[t]{2}{*}{ Mean } & \multirow{2}{*}{\begin{tabular}{c|c} 
Std. \\
Error
\end{tabular}} & \multicolumn{5}{|c|}{ 95\% Confidence Interval } \\
\hline & & & \multicolumn{2}{|l|}{$\begin{array}{l}\text { Lower } \\
\text { Bound }\end{array}$} & \multicolumn{2}{|c|}{ Upper Bound } & \\
\hline Graduate & 2.190 & .197 & \multicolumn{2}{|l|}{1.774} & \multicolumn{2}{|c|}{2.607} & \\
\hline Diploma & 1.750 & .438 & .826 & & \multicolumn{2}{|c|}{2.674} & \\
\hline \multicolumn{8}{|c|}{ Tests of Between-Subjects Effects } \\
\hline \multicolumn{8}{|c|}{ Dependent Variable: Heads' Scores } \\
\hline \multicolumn{2}{|c|}{ Source } & \multicolumn{2}{|c|}{$\begin{array}{c}\text { Type III Sum of } \\
\text { Squares }\end{array}$} & df & $\begin{array}{c}\text { Mean } \\
\text { Square }\end{array}$ & $\mathbf{F}$ & Sig. \\
\hline \multicolumn{2}{|c|}{ Corrected Model } & 6.14 & & 3 & 2.048 & 3.338 & .044 \\
\hline Interc & & 41.2 & & 1 & 41.297 & 67.320 & .000 \\
\hline Experie & & 4.3 & & 1 & 4.315 & 7.035 & .017 \\
\hline Education & evel & .51 & & 1 & .516 & .841 & .372 \\
\hline Experience $*$ Edu & ation Level & .13 & & 1 & .136 & .222 & .644 \\
\hline Erro & & 10.4 & & 17 & .613 & & \\
\hline Tota & & 113. & & 21 & & & \\
\hline Corrected & otal & 16.5 & & 20 & & & \\
\hline
\end{tabular}

Table 12: Two Way ANOVA Test Results

The test results in Table 12 showed that the participants with work experience from 1 to 4 years had different mean scores $(M=2.61)$ from those with work experience from 5 years and above $(M=1.33)$. The results indicated that the mean scores $(M=2.19)$ of the graduate participants were different from those $(M=1.75)$ of participants with diploma level of education.

The test revealed further that work experience had statistical significant effect on the school heads' mean scores of parents' knowledge of the policy guidelines $F(1,17)=7.04 ; p=.02$. Contrary to work experience, education level had no significant main effect on the named scores $F(1,17)=.84 ; p=.37$. The observed differences in descriptive distributions were, therefore, out of random chance. Findings indicated that work experience and education level of participants had no significant combined main effect on the participants' mean scores of parents' knowledge of the guidelines $\mathrm{F}(1,17)=22, \mathrm{p}=.64$.

School heads' work experience did influence their responses on parents' knowledge of the education policy guidelines probably due to their regular communication and contact with the parents. They had chances of getting informed about parents' knowledge in the course of managing the school community. Those with long experience in working with parents had different information from those with short experience. The results can be taken to be reliable and objective as the participants had different levels of experience and information regarding parents' knowledge of the education policy guidelines.

\section{Conclusions and Recommendations}




\subsection{Conclusions}

Based on the study findings, the researcher drew the following conclusions:

Generally, parents in Rukwa Region were aware of what the 2014 education policy guidelines provided for (through the circular number 3 of 2016) regarding their involvement in schools. Only a few parents did not know the policy guidelines. Hence, the communication of the policy to parents was, to a large extent, successful.

However, besides the fact that most parents knew the policy guidelines, their involvement in its implementation in the schools did not match with the knowledge level and it did not commensurate to the expected levels. Though parents' knowledge had influence on their participation in the implementation of the education policy and their involvement in general, the policy guidelines were inhibitive to some parents' involvement in schools.

School location and education level of the heads of schools had no significant effect on their scores on the parents' knowledge of the policy guidelines. However, their work experience had significant effects on their scores of the parents' knowledge of the policy guidelines.

\subsection{Recommendations}

From the findings of the study, the researcher made the following recommendations:

\subsubsection{Recommendations for Actions}

The study recommends that more efforts be made to clarify the policy guidelines to parents, especially on how to motivate parents to play their roles in the implementation of the education policy for its objectives to be attained.

\subsubsection{Recommendations for Further Studies}

Further studies can be carried out on: 1. Appropriate strategies for motivating parents to be involved in implementing education policy in ward schools in Rukwa Region, Tanzania, 2. Factors for the mismatch of parents' knowledge of education policy guidelines and their participation level in the implementation of fees free basic education policy in Rukwa Region.

\section{References}

i. Akar, H., \&Şen, D. (2017). Impact of internal migration movements on the schooling process in Turkey: Supervisors' views. Education Policy Analysis Archives, 25(13), 1 - 42. Retrieved from: https:// dx.doi.org/10.14507/epaa.25.2693

ii. Albez, C. and Ada, S. (2017). School administrators' skills in organizing the parent participation studies, Journal of Education and Training Studies, 5(4), 165 - 175. Retrieved from: https://doi.org/10.11114/jets.v5i4.2184

iii. Al-Onizat S. H. H. (2019). The effectiveness of an educational program in enhancing parents' level of knowledge about normal growth indicators in the development of children and determining the indicators which delay development in children from birth to three years old. Educational Research and Reviews14(9), 300-308, DOI: 10.5897/ERR2019.3719

iv. Andrews R. (2018). How Parental Education and Literacy Skill Levels Affect the Education of their Wards: The Case of Two Schools in the Effutu Municipality of Ghana. International Journal of Education and Practice, 2018, 6(3): 107-119 DOI:10.18488/journal.61.2018.63.107.119

v. Araque J. C., Wietstock C., Cova H.M., and Zepeda S. (2017). Impact of Latino Parent Engagement on Student Academic Achievement: School Community Journal. 27(2), 229 - 250.Available at

http://www.schoolcommunitynetwork.org/SCJ.aspx pp.

vi. Ary, D.; Jacobs, L.C.; and Sorensen, C.K. (2010). Introduction to Research. (8 $8^{\text {th }}$ Ed.) Wadsworth; CENGAGE Learning

vii. Babbie, E. (2008). The Basics of Social Research (4th Ed.). Belmont: Thomson Learning

viii. Bailey, K. D. (1994). Methods of Social Research (4th Ed.), New York: The Free Press

ix. Bernard, E. G. (2004). Perceived relevance of school boards in school improvement and leadership effectiveness in Musoma district council. (Masters Dissertation): UDSM

x. Bertrand M. and Rodela K. C. (2018). A Framework for rethinking educational leadership in the margins: Implications for social justice leadership preparation. Journal of Research on Leadership Education, 13(1) 10 37. DOI: $10.1177 / 1942775117739414$

xi. Bertrand, M., Freelon, R., \& Rogers, J. (2018). Elementary principals' social construction of parents of color and working-class parents: Disrupting or reproducing conflicting and deficit orientations of education policy? Education Policy Analysis Archives, 26(102), 1 - 37. http://dx.doi.org/10.14507/epaa.26.3546

xii. Best, J.W. and Kahn, J.V. (2006). Research in Education (10 ${ }^{\text {th }}$ Ed.), Boston: Pearson Education, Inc.

xiii. Charles, C.M. and Mertler, C.A. (2002). Introduction to Educational Research (4th Ed.). Boston: Allyn and Bacon

xiv. Chawe, M. (2017, July 15). Serikaliyakemeaupotoshajielimubure [The government rebukes misrepresentation of free education], Habarileo, p.4

xv. Clatworthy, F. J. (1969). The Formulation of British colonial education policy, 1929-1961. Final Report. Michigan University

xvi. Coombs, P.H. (1985). The World Crisis in Education: The View from the Eighties. New York: Oxford University Press 
xvii. Creswell, J.W. (2009). Research Design: Qualitative, Quantitative, and Mixed Methods Approaches. (3rd Ed). Los Angeles: SAGE Publications, Inc.

xviii. Creswell, J.W. and Clark, V. L. P. (2011). Designing and Conducting MixedMethods Research (2nd Ed.), London: SAGE Publications, Inc.

xix. Creswell, J.W. (2012). Educational Research: Planning, Conducting and Evaluating Quantitative and Qualitative Research. ( $3^{\text {rd }}$ Ed). Boston: Pearson Education, Inc.

xx. Creswell, J.W. (2014). Research Design: Qualitative, Quantitative, and Mixed Methods Approaches. (4th Ed). Los Angeles: SAGE Publications, Ltd.

xxi. Dror Y. (1968). Public Policymaking Re-examined. California: Chandler Publishing Co.

xxii. Fanuel, G. (2015). Parents' involvement in promoting students' academic performance in secondary schools in Same District, Tanzania. (Masters Dissertation): Mwenge Catholic University (MWECAU)

xxiii. Fernández E. and López G. R. (2017).When parents behave badly: A Critical policy analysis of parent involvement in schools. In Young, M. D., \& Diem, S. (Eds.). Critical Approaches to Education Policy Analysis. Moving Beyond Tradition(pp. 111 - 127). Springer DOI 10.1007/978-3-319-39643-9

xxiv. Fernández E and Scribner P. S. M. (2018). 'Venimos para que se oiga la voz': Activating community cultural wealth as parental educational leadership. Journal of Research on Leadership Education. 13(1) 59-78. DOI: $10.1177 / 1942775117744011$

xxv. Field, A. (2009). Discovering Statistics using SPSS (3 $3^{\text {rd }}$ Ed.), London: SAGE Publications

xxvi. Field, A. (2013). Discovering Statistics using SPSS (4th Ed.), Los Angeles: SAGE Publications Ltd

xxvii. Focus, S. (2010). Internal efficiency of community secondary schools in Maswa district. (Masters Dissertation): UDSM

xxviii. Forojalla, S.B. (1993). Educational Planning for Development. London: The McMillan Press Ltd

xxix. Gall, M.D, Gall, J.P. and Borg, W.R. (2007). Educational Research: An Introduction (8 ${ }^{\text {th }}$ Ed.). Boston: Pearson Education, Inc.

xxx. Gay, L.R. (1987). Educational Research: Competencies for Analysis and Application (3 ${ }^{\text {rd }}$ Ed.). Ohio: Merrill Publishing Company

xxxi. Gay, L. R.; Mills, G. E.; and Airasian, P. (2012)Educational Research: Competencies for Analysis and Applications (10 th Ed.) Boston: Pearson Education, Inc.

xxxii. Haddad, W. D. (1995). Educational Policy Planning Process: An Applied Framework Paris: UNESCO International Institute for Educational Planning

xxxiii. Hakielimu (2017). Impact of the implementation of fee-free education policy on basic education in Tanzania: A qualitative study. Research report: Da es Salaam

xxxiv. Heystek, J. (2003). Parents as governors and partners in schools Education and Urban Society, 35 (3), 328-351. DOI: $10.1177 / 0013124503035003005$

xxxv. Heystek, J. (2011). Governing bodies in South African Schools: Under pressure to enhance democratization and improve quality, Educational Management Administration \& Leadership, 39(4), 455-468. DOI: $10.1177 / 1741143211406149$

xxxvi. Iimene T. (2015). Perceptions of Teachers and Parents Regarding the Implementation of the Education Sector Policy for the Prevention and Management of Learner Pregnancy: A Case Study of Oshigambo Inspection Circuit in Namibia M.Ed. Dissertation. The University of Namibia

xxxvii. İlik S.S. and KonukEr R. (2019). Evaluating Parent Participation in Individualized Education Programs by Opinions of Parents and Teachers. Journal of Education and Training Studies. 7(2), 76 - 83: doi:10.11114/jets.v7i2.3936

xxxviii. Ismail, B. (2017, January, 27). Wazazi, Waleziwawekangumumchangowachakulashuleni [Parents, guardians resist contribution for food in schools]; Mwananchi News Paper, Local News, p.8

xxxix. Kabir, A. H. and Akter, F. (2014). Parental involvement in the secondary schools in Bangladesh: Challenges and the way forward. International Journal of whole schooling, 10(1), 1 - 8. https://files.eric.ed.gov/fulltext/EJ1030575.pdf

xl. Johnson R. B. and Christensen L. (2017). Educational Research. Quantitative, Qualitative, and Mixed Approaches (6th Ed.). London: SAGE Publications, Ltd

xli. Kalolo, F.J. (2016). Craving for quality education in Tanzania: Dispelling the myths. Journal of Education Issues, 2(1), 57 - 69. DOI:10.5296/jei.v2i1. 8506

xlii. Kerlinger, F. N. and Lee, H.B. (2000). Foundations of Behavioral Research (4 ${ }^{\text {th }}$ Ed.), London: Earl McPeek

xliii. Khan, A. R. and Khandaker, S. (2017). A Critical insight into policy implementation and implementation performance. Public Policy and Administration 15(4), 538 - 548. DOI: 10.13165/VPA-16-15-4-02

xliv. Kiilu R.M. and Mugambi L. (2019). Status of school feeding programme policy initiatives in primary schools in Machakos County, Kenya African Educational Research Journal, 7(1), 33-39. DOI: 10.30918/AERJ.71.18.107

xlv. Kombo, D. K and Tromp, D.L.A. (2006). Proposal and Thesis Writing: An Introduction. Nairobi: Paulines Publications Africa

xlvi. Krathwohl, D.R. (2009). Methods of Educational Science Research: The Logic of Methods (3 ${ }^{\text {rd }}$ Ed.), Illinois: Waveland Press, Inc.

xlvii. Lawuo, E. A.; Machumu, H. J.; and Kimaro, A. R. (2015) Uncovered coping strategies adopted by children living in homes with marital conflicts for their own survival Journal of Education and Practice,6(18), 114 - 129. https://files.eric.ed.gov/fulltext/EJ1079722.pdf 
xlviii. LiCalsi C. Ozek U. and Figlio D. (2016). The Uneven Implementation of Universal School Policies: Maternal Education and Florida's Mandatory Grade Retention Policy. SREE Spring Conference Abstract Template

xlix. Lukwata, J.; Ogula,P.A.; Ryan, P.; Ayako, A.; Wakah, G. and Onsongo, J. (2014). Paths of development CCR - IFCU poverty reduction research project report, An Assessment of the Kenya government's revolving loan funds programmes and the Catholic Church's self-help group approach projects. Nairobi; CUEA Press

l. Maendaenda, T. (2010). Causes and patterns of dropouts in community secondary schools: A case study of Korogwe town council, Republic of Tanzania. (Masters Dissertation): UDSM

li. Magava, 0.J. (2015). Constraints on the successful implementation of the universal and compulsory primary education policies in Tanzania, 1967 - 2013. (PhD Education Dissertation): UDSM

lii. Makenya, M. H. (2013). Levels of parental involvement in public secondary schools management in Moshi municipality. Unpublished (Masters Dissertation): MWECAU

liii. Komba, S. C. and Makwinya, N. M (2014). Community - school partnership in Tanzania: The Role of parents' perceptions regarding communication and democracy in the partnership. Journal of Education; 2 (12), 1 - 14. https://www.researchgate.net/publication/270583551

liv. Masue, O.S. (2014). Empowerment of school committees and parents in Tanzania: Delineating existence of opportunity, its use and impact on school decisions. (PhD Dissertation): University of Bergen. Retrieved from http://citeseerx.ist.psu.edu/viewdoc/download?doi=10.1.1.841.2866\&rep=rep1\&type=pdf

lv. Matekere, Y.M. (2003). Effectiveness of community secondary schools in Tanzania. A Case of Mvomero district. (Masters Dissertation): UDSM

lvi. Mbugua, F. and Rarieya, J.F.A. (2014). Collaborative Strategic Planning: Myth or Reality? Educational Management Administration \& Leadership, 42(1), 99-111. DOI: 10.1177/1741143213499258

lvii. Mhegera, I.E. (2011). Sumbawanga ward secondary schools report. Retrieved from mhegeraelias.blogspot.com/2011/12/Sumbawanga-ward-secondary-schools-report.html Retrieved on $22 / 06 / 2017$

lviii. Morrison, K.; Manion, L and Cohen, L. (2011). Research Methods in Education (7th Ed.) London: Routledge

lix. Morse, J.M.; Barrett, M.; Mayan, M.; Olson, K. and Spiers, J. (2002).Verification strategies for establishing reliability and validity in qualitative research. International Journal of Qualitative Methods 1(2), 13 - 20. Retrieved on 21/09/2017 from: journals.sagepub.com/doi/pdf/10.1177/160940690200100202

lx. Mosha, H. J. (2006). Planning Education Systems for Excellence, Dar es Salaam: E\&D Limited

lxi. Mshani, G. (2015). Poverty indicators affecting academic performance in Tanzania secondary schools at Nkasi district, (Masters Dissertation): OUT

lxii. Mualuko, N.J and Limukii, K.E. (2012). The free education policy in Kenya: A critique; International Journal of Education Administration and Policy Studies, 4 (1), 1-5. DOI: 10.5897/IJAPS10.031

lxiii. Mugenda, O.M and Mugenda, A. G. (1999). Research Methods: Quantitative \& Qualitative Approaches. Nairobi: Acts Press

lxiv. Munishi, M.P. (2014). The assessment of heads of schools' managerial competency after attending in-service training in Coast Region, (Masters Dissertation): UDSM

lxv. Nachmias, C. F. and Nachmias, D. (1996). Research Methods in the Social Sciences (5th Ed). London: St Martin's Press, Inc.

lxvi. Ndasi, A. K. (2003). Factors affecting secondary school administration in Sumbawanga District, Tanzania. (Masters Dissertation): Catholic University of Eastern Africa

lxvii. Ngalawa, A.; Simmt, E. and Glanfield, F. (2015). Exploring the emergence of community support for school and encouragement of innovation for improving rural school performance: Lessons learned at Kitamburo in Tanzania. Global Education Review, 2 (4). 101 - 119. https://files.eric.ed.gov/fulltext/EJ1080909.pdf

lxviii. Nyandwi, D.M. (2014). Determinants of poor academic performance of secondary school students in Sumbawanga district, Tanzania, (Maters Dissertation): Sokoine University of Agriculture (SUA)

Ixix. Okeke, C.I. (2014). Effective home - school partnership: Some strategies to help strengthen parental involvement, South African Journal of Education, 34(3), 1 - 8 of the article. http://sajournalofeducation.co.za/index.php/saje/article/viewFile/864/445

Ixx. Olayiwola, S. and Alabi, K. (2015). The Micro-politics of school principals' decision making in Nigeria. International Journal of Educational Leadership and Management, 3(2), 173 - $191 . \quad$ DOI: 10.17583/ijelm.2015.1441

lxxi. Punch, K.F. (2009). Introduction to Research Methods in Education. London: SAGE Publications Ltd

lxxii. Rodela K. C. and Bertrand M. (2018) Rethinking educational leadership in the margins: Youth, parent, and community leadership for equity and social justice. Journal of Research on Leadership Education 13(1) 3 - 9, DOI: $10.1177 / 1942775117751306$

lxxiii. Salema, V. (2009). An Evaluation of the implementation of ... government - community secondary schools in Rombo District, Kilimanjaro - Tanzania. (Masters Dissertation): Catholic University of Eastern Africa (CUEA)

lxxiv. Salema, V. (2014). Assessment of the implementation of learner centred pedagogy in public and private secondary schools in Kilimanjaro region, Tanzania. (PhD Dissertation): CUEA

lxxv. Scribner, S. M. P., \&Fernández, E. (2017). Organizational politics of parental engagement: The intersections of school reform, anti-immigration policies, and Latina parent organizing. Educational Policy, 31(6), 895-920. DOI: $10.1177 / 0895904817719527$

lxxvi. Siyame, P. (2016, October 11). Parents with truant children on the run in Rukwa, Daily news, Home news, p.2 
Ixxvii. Sumarsono, R.B; Imron, A; Wiyano, B.B. and Arifin, I. (2016). Parents' participation in improving the quality of elementary school in the city of Malang, East Java, Indonesia. International Education Studies, 9(10), 256 - 262. DOI: $10.5539 /$ ies.v9n10p256

lxxviii. Sunardi S., Maryadi M. \&Sugini S. (2014). The Effectiveness of a two-day inclusion workshop on teachers' attitudes, understanding, and competence in inclusive education. World Journal of Education, 4(5), 77 - 85. doi:10.5430/wje.v4n5p77

lxxix. Teddlie, C. and Yu, F. (2007).Mixed methods sampling: A typology with examples. Journal of Mixed Methods Research, 1(1), 77 - 100. DOI: 10.1177/2345678906292430

lxxx. Tesha, P.S. (2012). Analysis of the role of school leadership in promoting academic and social development of the school in Meru community. Focus on governmentsecondary schools. (Masters Dissertation): UDSM

lxxxi. URT (1978). Education Act No 25. Dar es Salaam: Ministry of Education and Vocational Training (MoEVT)

lxxxii. URT (1995). Education and Training Policy. Dar es Salaam: MoEVT

lxxxiii. URT (2002). The Education Act. Chapter 353. Dar es Salaam: MoEVT

lxxxiv. URT (2004). Education Sector Development Programme: Secondary Education Development Programme (SEDP). Dar es Salaam: MoEVT

Ixxxv. URT. (2013). 2012 Population and Housing Census: Population Distribution by Administrative Areas, Dar es Salaam: Ministry of Finance

lxxxvi. URT (2014). Education and Training Policy, Dar es Salaam: MoEVT

lxxxvii. URT (2015). Secondary School Management Toolkit (SSMT), Practical Guide for Heads of Schools: MoEVT

lxxxviii. URT (2015). Warakaelimunamba 6 wamwaka 2015 kuhusuutekelezajiwaelimumsingibilamalipo [Education circular number 6 of 2015 on implementing fees free basic education] Dar es salaam: MoEVT

lxxxix. URT (2016). Warakawaelimunamba 3 wamwaka 2016 kuhusuutekelezajiwaelimumsingibilamalipo [Education circular number 3 of 2016 on implementing fees free basic education].Ministry of Education, Science and Technology (MoEST)

xc. URT (2016, February 29).

Utaratibuwautoajiwawavibalivyakuchangiakwahiarimahitajikwaajiliyakutatuakerozilizoposhuleni [Procedure for granting permits for voluntary contributions for allaying challenges in schools]. Dodoma: Tawalaza Mikoana Serikaliza Mitaa (TAMISEMI)

xci. Vavrus, F. (2003). Desire and Decline: Schooling Amid Crisis in Tanzania. New York: Peter Lang Publishing, Inc.

xcii. Welton, A., \& Freelon, R. (2018). Community organizing as educational leadership: Lessons from Chicago. Journal of Research on Leadership Education, 13(1), 79-104. DOI: 10.1177/1942775117744193

xciii. Yassin, I. (2017, January 31). A Teacher caned for punishing a student. Tanzania Daima, News, p. 2

xciv. Zahara, A. (2014). Factors hindering effective parental involvement in children's schooling in public primary schools in Kinondoni municipality, Tanzania. (Masters Dissertation): UDSM 